\author{
G.A. Kambarbekova* \\ Al-Farabi Kazakh National University, Kazakhstan, Almaty, \\ *e-mail: qazigurt2016@gmail.com
}

\title{
AL-FARABI AND HIS TREATISES, WHICH ARE BASED ON PRACTICE
}

The article examines the life and little-known works of the famous scientist encyclopedist Abu Nasr Al-Farabi. A native of the Kazakh steppe, he is widely known for his deep knowledge and mastery of various disciplines. Abu Nasr Al-Farabi wrote treatises, articles and commentaries on various fields of science. According to the established tradition, Abu Nasr Al-Farabi is primarily a philosopher. He is also known for his individual treatises on all areas of the humanities. His treatises on mathematics and music have been translated into many languages of the world and are widely recognized. However, Al-Farabi's works on medicine and chemistry are not widely known. For this reason, the article examines the small treatises of a famous scientist in the natural sciences and is considered from a modern point of view. Abu Nasr Al-Farabi's works on natural sciences were translated into Russian on the eve of the $1100^{\text {th }}$ anniversary of the scientist. Much time has passed since then, and these treatises have not received wide recognition. The article examines Al-Farabi's work on medicine and chemistry in the light of current events. Every treatise by Al-Farabi is valuable, but his work on natural sciences allows us to get to know the scientist from a different angle.

Key words: Al-Farabi, treatise, philosophy, logic, medicine, chemistry, anatomy, botanic, biology, natural sciences.

$$
\begin{gathered}
\text { Ғ.Ә. Қамбарбекова* } \\
\text { Әл-Фараби атындағы Қазақ, ұлттық, университеті, Қазақстан, Алматы қ., } \\
\text { "e-mail: qazigurt2016@gmail.com } \\
\text { Әл-Фараби мен оның тәжірибеге негіздемген трактаттары }
\end{gathered}
$$

Мақалада танымал энциклопедист ғалым Әбу Наср әл-Фарабидің өмірі мен аз танылған еңбектері қарастыралады. Қазақ даласының тумасы терең білімі мен жан-жақты пәндерді игергендігімен кең танылған. Әбу Наср әл-Фараби ғылымның түрлі саласын қамтитын трактаттар, мақалалар және өзінен бұрын өмір сүрген ғалымдардың еңбектеріне түсініктер жазған. Қалыптасқан дәстүр бойынша Әбу Наср әл-Фараби ең алдымен философ. Сонымен қатар, гуманитарлық ғылымның барлық саласына жеке-жеке трактат арнағандығымен де белгілі. Математика мен музыкаға арналған трактаттары әлемнің көптеген тілдеріне аударылып кең түрде танылған. Алайда әл-Фарабидің медицина мен химия салаларына арнап жазған еңбектерін көпшілік қауым біле бермейді. Сол себепті мақалада танымал ғалымның жаратылыстану ғылымына арнаған шағын еңбектері қарастырылып, бүгінгі заман тұрғысынан талқыланады. Әбу Наср әлФарабилің жаратылыстану ғылымына арнаған еңбектері ғалымның 1100 жылдық мерейтойы қарсаңында орыс тіліне аударылып жарық көрген. Сол кезден бері ұзақ уақыт өтті және аталмыш еңбектер кең түрде таныла қоймады. Мақалада әл-Фарабидің медицина мен химияға қатысты еңбектерінің қазіргі уақыттағы өзгерістер тұрғысынан талқыланады. Әл-Фарабидің әрбір трактаты құнды, бірақ жарытылыстану ғылымына арнаған еңбектері ғалымды басқа қырынан тануға мүмкіндік береді.

Түйін сөздер: Ә^-Фараби, трактат, философия, ^огика, медицина, химия, анатомия, ботаника, биология, жаратылыстану ғылымдары.

\author{
Г.А. Камбарбекова* \\ Казахский национальный университет имени аль-Фараби, Казахстан, г. Алматы, \\ *e-mail: qazigurt2016@gmail.com
}

А^ь-Фараби и его трактаты, которые основаны на практике

В статье рассматриваются жизнь и малоизвестные труды известного ученого-энциклопедиста Абу Насра аль-Фараби. Уроженец казахской степи широко известен своими глубокими знаниями и владением различными дисциплинами. Абу Наср аль-Фараби писал трактаты, статьи и комментарии по различным областям науки. По устоявшейся традиции Абу Наср аль-Фараби 
прежде всего философ. Он также известен своими индивидуальными трактатами по всем областям гуманитарных наук. Его трактаты по математике и музыке переведены на многие языки мира и получили широкое признания. ОАнако труды А^ь-Фараби по медицине и химии широко не известны. По этой причине в статье рассматриваются небольшие труды известного ученого по естественным наукам с современной точки зрения. Работы Абу Насра аль-Фараби по естественным наукам были переведены на русский язык накануне 1100-летия ученого. С тех пор прошло много времени, а эти работы не получили широкого признания. В статье рассматриваются работы А^ь-Фараби по медицине и химии в свете текущих событий. Каждый трактат Аль-Фараби ценен, но его работы по естественным наукам позволяют нам узнать ученого с Аругой стороны.

Кмючевые слова: А^ь-Фараби, трактат, философия, ^огика, медицина, химия, анатомия, ботаника, биология, естественные науки.

\section{Introduction}

This year Kazakhstan celebrates the $1150^{\text {th }}$ anniversary of the birth of Abu Nasr Al-Farabi. Earlier, the anniversary of Al-Farabi was widely celebrated in the Soviet Union in 1975 in Moscow, Baghdad and Almaty. On the eve of Farabi's anniversary, the Institute of Philosophy and Law of the Kazakh Academy of Sciences translated several treatises of Abu Nasr Al-Farabi directly from the Arabic language into the Kazakh and Russian languages (Al-Farabi, 1972-1975). Although, given that many treatises of great scientists have not even now reached some remote places, these books cannot be found in the libraries of the regions. In subsequent years, the Institute of Philosophy continued to pay attention to the Farabi Studies and published a number of other major treatises of this scientist (Al-Farabi, 1987). Each of these books is the result of many years of work by a large scientific team. In recent years, a number of fundamental works have been carried out within the framework of various state programs. Nevertheless, given that many treatises of great scientists have not even now reached some remote places, these books have not been found in regional libraries. It should be emphasized that the works of Al-Farabi were published for a long time, a lot of time has passed since their publication and the books published became rare editions that are less accessible to readers. Surely, in recent years, within the framework of various state programs, several fundamental works have been carried out, and Farabi's works have been widely promoted. Nevertheless, taking into account the fact that, no matter how much Al-Farabi's works are studied, it was known that many of his works have not still reached some remote places and the works of Abu Nasr Farabi are not available in regional libraries. Accordingly, as part of this year's celebration of the $1150^{\text {th }}$ anniversary of the encyclopedic scientist, if we ask ourselves what we know about Abu Nasr AlFarabi, we will make sure we know a little. It is no wonder that the works of Al-Farabi, translated into Kazakh and Russian, have not yet reached a wide range of readers, especially in rural areas, and that young people, especially pupils and students, are not familiar with the works of the famous scientist from Otrar. Pupils, students and a wide range of readers are asking a logical question: "Does Al-Farabi have works in all branches of science, especially in chemistry, biology, anatomy, and medicine". Yes, the scientist has written short treatises and articles on each of these disciplines.

Justification of the choice of the article and goals and objectives

Although Al-Farabi was best known for his philosophical analyses his major treatises belongs to philosophy, and he was known as the "Second Master". It is not known how many treatises the scientist wrote. Definitely, many readers know that he has books on logic, music, philosophy, mathematics and politics. Nevertheless, the question arises whether all of his works reached the Kazakh reader or whether they have been translated. More than twenty books of the scientist have been translated and published in Kazakh and Russian languages. Most of his works are devoted to philosophy, logic, politics, music, mathematics, society and politics. It is noticeably that each of these works is difficult to understand even in the original language, and the meaning becomes increasingly difficult to understand in the translated texts. Meantime, the scientist has short and laconic works on natural science. AlFarabi's treatises on medicine, anatomy, biology and chemistry were published many years ago. The purpose of this article is to review the less well-known treatises of a natural science.

\section{Scientific research methodology}

The article uses the analytical and historicalcomparative method. Furthermore, all scientific methods used in research work are used. 


\section{Results and discussion}

Abu Nasr Muhammad ibn Tarkhan ibn Uzlag Farabi was born in Otrar in 870 and died in Damascus, Syria, in 950-951. Very little known of Al-Farabi's early life and studies. Although, scholars believe that Abu Nasr Muhammad did not come from a poor family, as his father was a military officer. The word "Tarkhan" means a military position. As for his primary studies, where and in which madrasah he studied, scientists unanimously declare that the smart boy first received his primary education in one of the local madrasahs, and then went to Baghdad (Corbin, 1373/1994: 224). At that time, a group of Iranian scholars believed that before leaving for Baghdad, young Farabi first studied in Samarkand, Bukhara, and then in the Iranian cities of Rey and Hamadan (Halabi, 2002: 146). As reported by Uzbek scientist M. Khairullaev, Al-Farabi received his primary education at home, visited Shash and Samarkand, and worked in Bukhara. He lived in Iran and studied various branches of science. He became famous as a scientist after he settled in Baghdad (Khairullaev, 1973: 10).

It should be pointed out that Iranian scholars believe that Farabi was Iranian origin. In Iran, the scientist's works are widely studied and widely promoted. In Iran, the work of Farabi is highly appreciated and recognized as the founder of Islamic philosophy. Accordingly, Iran has an International Farabi Award, Farabi festival, Research Center, an institute, a publishing house, a film studio and children's centers in merit of Abu Nasr Al-Farabi. The name Abu Nasr Al-Farabi is also widespread in the Arab world. Unsurprisingly if a scholar who spent his entire life between the Arabs and wrote in Arabic is named an Arab scholar. Arab, Persian and Turkish scholars took an active part in the study and promotion of al-Farabi's treatises. Western scholars have traditionally been actively involved in the study of the scholar's treatises and translated into French, German, English, Hebrew and Russian.

Still do not know how many treatises Abu Nasr Al-Farabi wrote. It is not easy to estimate the exact number of Farabi's works, primarily, because of the large number of his works, and next, because of the late interest of researchers in Farabi's works. Nevertheless, some scholars have named the approximate amount of Al-Farabi's work. As for instance, M. Khairullaev writes that Al-Farabi wrote more than 160 treatises covering almost all branches of natural science and humanitarian knowledge of the Middle Ages (Khairullaev, 1973, p. 16). Nevertheless, despite the fact that the names of 160 treatises are found in various medieval collections and are mentioned in the works of scientists of the Middle Ages, about 70 treatises of Al-Farabi are known to modern science.

Abu Nasr Farabi received a comprehensive education in Baghdad. Before coming to Baghdad, he studied in Central Asia and Iran, but was recognized as a scholar in Baghdad, the capital of the Abbasid Caliphate. We still do not know how many treatises Abu Nasr Al-Farabi wrote. We still do not know how many treatises Abu Nasr Al-Farabi wrote. It is not easy to estimate the exact number of Farabi's works, firstly, because of the large number of his works, and second point is because of the late interest of researchers in Farabi's works. Even though, some scholars have named the approximate amount of Al-Farabi's work. For example, M.Khairullaev writes that Al-Farabi wrote more than 160 treatises covering almost all branches of natural science and humanitarian knowledge of the Middle Ages (Khairullaev, 1973, p. 16). Nevertheless, despite the fact that the names of 160 treatises are found in various medieval collections and are mentioned in the works of scientists of the Middle Ages, about 70 treatises of Al-Farabi are known to modern science.

Abu Nasr Farabi received a comprehensive education in Baghdad. Before coming to Baghdad, he studied in Central Asia and Iran, but was recognized as a scholar in Baghdad, the capital of the Abbasid Caliphate. It is well-known that the world's first general education institution of higher education "Bayt al-Hikma" was established in Baghdad (Britannica: Bayt al-Hikma). The word translates as "House of Wisdom". The "House of Wisdom" functioned at the level of today's university and Academy, where many Eastern scholars and thinks were educated. One of them is the many scholars who graduated from the House of Wisdom - Abu Nasr Al-Farabi. Abu Nasr Al-Farabi evidently did not choose a specific branch of science, but began to study every branch of science and brought all knowledge to perfection. However, philosophy has been recognized as the father of science since ancient times, especially in the Middle Ages. Therefore, Abu Nasr alFarabi first began his scientific career in the field of philosophy. Along with philosophy, he studied logic, ethics, grammar, sociology, politics, society, music, astronomy, physics, mathematics, geometry, optics, vacuum, chemistry, medicine, botany, biology, linguistics, literature, poetry and mastered many other disciplines. Al-Farabi, known as a philosopher in the Islamic world, made a great contribution to the field of philosophy. Throughout the Muslim East, many scholars unanimously recognize Abu Nasr alFarabi as the first Muslim philosopher and founder 
of Islamic philosophy, as well as scholars who have dedicated works to all branches of science (Sadri, 1374: 32). There is a peculiar reason for this conclusion. Above all, Abu Nasr Al-Farabi occupies a special place as a scientist who introduced the Muslim countries of the East to ancient philosophy. It is well-known that he wrote commentaries on Aristotle's natural sciences. That is why he was known as "Muallim al-sani", the Second Master. The philosophical ideas of Western scholars used to be alien to the Muslim world, but now Western thinkers have approached the Eastern community thanks to the works of Al-Farabi. Second point is that, Al-Farabi himself paid a lot of attention to philosophy, society, public government, politics and culture, and also wrote separate works on these topics. It is not easy to estimate the exact number of Farabi's works, firstly, because of the large number of his works, and next, because of the late interest of researchers in Farabi's works. Nevertheless, some scholars have named the approximate amount of Al-Farabi's work. As for instance, M. Khairullaev writes that Al-Farabi wrote more than 160 treatises covering almost all branches of natural science and humanitarian knowledge of the middle Ages (Khairullaev, 1973, p. 16). However, despite the fact that the names of 160 treatises are found in various medieval collections and are mentioned in the works of scientists of the middle Ages, about 70 treatises of Al-Farabi are known to modern science.

Abu Nasr Farabi received a comprehensive education in Baghdad. Before coming to Baghdad, he studied in Central Asia and Iran, but was recognized as a scholar in Baghdad, the capital of the Abbasid Caliphate. It is well-known fact that the world's first general education institution of higher education "Bayt al-Hikma" was established in Baghdad (Britannica: Bayt al-Hikma). The word translates as "House of Wisdom". The "House of Wisdom" functioned at the level of today's university and Academy, where many Eastern scholars and thinks were educated. One of them is the many scholars who graduated from the House of Wisdom - Abu Nasr al-Farabi. Abu Nasr al-Farabi apparently did not choose a specific branch of science, but began to study every branch of science and brought all knowledge to perfection. Nevertheless, philosophy has been recognized as the father of science since ancient times, especially in the Middle Ages. Therefore, Abu Nasr al-Farabi first began his scientific career in the field of philosophy. Along with philosophy, he studied logic, ethics, grammar, sociology, politics, society, music, astronomy, physics, mathematics, geometry, optics, vacuum, chemistry, medicine, botany, biology, linguistics, literature, poetry and mastered many other disciplines. Al-Farabi, known as a philosopher in the Islamic world, made a great contribution to the field of philosophy. Throughout the Muslim East, many scholars unanimously recognize Abu Nasr al-Farabi as the first Muslim philosopher and founder of Islamic philosophy, as well as scholars who have dedicated works to all branches of science (Sadri, 1374: 32). There is a peculiar reason for this conclusion. First of all, Abu Nasr Al-Farabi occupies a special place as a scientist who introduced the Muslim countries of the East to ancient philosophy. It is well-known that he wrote commentaries on Aristotle's natural sciences. That is why he was called "Muallim al-sani", the Second Master. The philosophical ideas of Western scholars used to be alien to the Muslim world, but now Western thinkers have approached the Eastern community thanks to the works of Al-Farabi. Second point is that, Al-Farabi himself paid a lot of attention to philosophy, society, public government, politics and culture, and also wrote separate works on these topics.It is known fact that the world's first general education institution of higher education "Bayt alHikma" was established in Baghdad (Britannica: Bayt al-Hikma). The word translates as "House of Wisdom". The "House of Wisdom" functioned at the level of today's university and Academy, where many Eastern scholars and thinks were educated. One of them is the many scholars who graduated from the House of Wisdom - Abu Nasr al-Farabi. Abu Nasr Al-Farabi ecidentlydid not choose a specific branch of science, but began to study every branch of science and brought all knowledge to perfection. Although, philosophy has been recognized as the father of science since ancient times, especially in the Middle Ages. Consequently, Abu Nasr Al-Farabi first began his scientific career in the field of philosophy. Along with philosophy, he studied logic, ethics, grammar, sociology, politics, society, music, astronomy, physics, mathematics, geometry, optics, vacuum, chemistry, medicine, botany, biology, linguistics, literature, poetry and mastered many other disciplines. Al-Farabi, known as a philosopher in the Islamic world, made a great contribution to the field of philosophy. Throughout the Muslim East, many scholars unanimously recognize Abu Nasr al-Farabi as the first Muslim philosopher and founder of Islamic philosophy, as well as scholars who have dedicated works to all branches of science (Sadri, 1374: 32). There is a peculiar reason for this conclusion. Above all, Abu Nasr Al-Farabi occupies a special place as a scientist who introduced the Muslim countries of the East to ancient philosophy. 
It is well known that he wrote commentaries on Aristotle's book on natural sciences. That is why he was known as "Muallim al-sani", the Second Master. The philosophical ideas of Western scholars used to be strange to the Muslim world, but now Western thinkers have approached the Eastern community thanks to the works of Al-Farabi. Furthermore, AlFarabi himself paid a lot of attention to philosophy, society, public government, politics and culture, and also wrote separate works on these topics. These are: "Virtuous city", "Politics in the city", "Philosophical Treatises", "Reason and Science", "Fusus al-Hikam", "Logic" and many others. Reading the philosophical thoughts of Farabi, we will make sure that the scientist calls for humanity, friendship, organized work, respect and the search for knowledge. He emphasized that the real happiness of people is a constant search for knowledge and science, selfdevelopment through gained knowledge. In addition, Abu Nasr Al-Farabi paid special attention to the morality of people. According to al-Farabi, good and evil comes from human behavior. If a person is educated, competent, but has a bad morality, then evil will spread where this person exists, and his evil will destroy society. Studying science helps to fight against the base passions of people, to overcome the negative phenomenon found in society. Therefore, it is very important to be engaged in science, but it is even more important to have good morality. Abu Nasr Al-Farabi in several treatises emphasized that if a person does not possess high moral qualities and virtues, he cannot achieve noticeable success in science (Al-Farabi, 1987: 18-19).

Al-Farabi's contributions influenced Muslim philosophers who succeeded him, particularly Ibn Sina and sparked what became an ongoing debate between proponents of philosophy and those who asserted superiority of theology. Al-Farabi, as the founder of Islamic philosophy, was a role model for many other scholars. Many Muslim scholars who lived after al-Farabi, after becoming acquainted with the works of Abu Nasr Al-Farabi, came to science. One of them is Ibn Sina (980-1037). Ibn Sina wrote about al-Farabi in his book: "When I started to study theology (Divine Teaching), I began my acquaintance with Aristotle's book "Ma baad at-tabiyya" (Treatise on Natural Sciences). No matter how much I read this book, I could not find what I needed. I have read this book forty times. I even learned all the words of the book, but I still could not understand the author's thoughts. When I lost hope, one day I went to the market. At the market, a bookseller offered to buy a small book. He said the book was only worth three dirhams.
Later, I was madly glad to learn that this book was a commentary by Al-Farabi to the book of Aristotle. I just read Farabi's commentary on Aristotle's book just once and understood all the fundamental ideas of Aristotle" (Halabi, 2002: 156). From the words of Ibn Sina, it should be noted that Farabi could present complex philosophical works to the reader understandably.

Regarding the principal topic, it is not surprising that Abu Nasr Al-Farabi well acquainted with medicine and chemistry. In the Middle Ages, they taught not only religion and language in madrasahs, but all the sciences necessary for human life. In modern society, the teaching of several subjects in schools and universities comes from the education system of the Middle East. On the one hand, this means we have discovered nothing new, but next it shows that European countries received such a complex education system from the medieval Muslim East.

In the medieval East, they believed it that an educated person should know the language, literature, religion, mathematics, medicine, astronomy and so on. Therefore, anyone who studied in a madrassa introduced to medicine at a level that allows one to self-medicate, or at the level that a person was able to use suitable medicinal herbs. The shagirds were introduced to the basics of botany, anatomy and biology. And then they introduced to the basic courses of medicine craft. When we talk about medicine craft in the medieval East botany, biology, and anatomy are all considered together. Including chemistry on this list is complete this list and necessary process. Because we cannot imagine medicine without biology, and also cannot be considered without chemistry. As we see, Al-Farabi constantly focused on one area of science, then the second, the third, and then the fourth. The fields of science are as close as family members. When there is a need to study medicine, then you need to study its relatives too. And when studying a language, such disciplines as literature, religion, history, philosophy, logic, ethics, poetics, psychology studied together, because these related disciplines, and only then the researcher's outlook expands.

Abu Nasr Al-Farabi's work on medicine and chemistry has been studied by many scientists around the world. Among them, the Uzbek scientist M. Khairullaev deserves special mention (Khairullaev, 1973: 16-17). He was one of the first to study and analyze Abu Nasr Al-Farabi's treatises on medicine and chemistry. Kazakhstan's scientists have translated several short treatises of Farabi on natural science and presented them to the readers (Al-Farabi, 
1987). This collection includes Al-Farabi's valuable works on medicine, physics, chemistry, anatomy and biology. In addition, during the Soviet era, several articles written on the study of Al-Farabi's treatise on medicine. This is G.Z.Pizchelauri (Pichkhelauri, 1971: 75-77), S.B.Balmukhanov (Balmukhanov, 1975: 64-67), A.R.Chokin (Chokin, 1976: 3-5), A.A.Kaziberdiev (Kaziberdiev, 1978: 134-136). Many of these articles were written on the eve of the $1100^{\text {th }}$ anniversary of Al-Farabi. In recent years, Badr El-Fakkak researched Al-Farabi's treatise on medicine and used in his doctoral dissertation named «Cosmic Justice in Al-Farabi's Virtuous city». AlFakkak compares the work of a head of state with that of a doctor. When he explains the medical term "virtuous craft" from a medical point of view, he compared a physician's ability to heal a person to a supreme leader's ability to run a virtuous city (ElFekkak, 2012: 117-118).

Abu Nasr Al-Farabi has three short but valuable treatises on medicine and chemistry. The first work is "On the Organs of the Human Body". This treatise' other name is - On the objection to Galen regarding his disagreement with Aristotle regarding the organs of the human body. The second treatise by Abu Nasr Al-Farabi is - On the organs of animals, their functions and capabilities. The third treatise of AlFarabi is "On the necessity of the art of chemistry". The first two treatises are based on the works of the famous Greek philosopher Aristotle (384-322 BC) and the physician-writer Claudius Galen (130-200 $\mathrm{BC}$ ). The researchers compared the works of Greek scientists with the works of Al-Farabi and came to the following conclusion that Abu Nasr Al-Farabi also included his views in his treatises on medicine.

Al-Farabi, at the very beginning of his treatise "On the Necessity of the Art of Chemistry," noted that he wrote this little work to resolve the dispute between false alchemists and those who reject this science. In the Middle Ages, many people practiced the art of alchemy. Often the goal of alchemists was to find the "Philosopher's stone" and with its help turn cheap melalls into gold and silver. The goal is to sell them and make huge profits. In addition, alchemists wanted to find an "elixir of life" that would heal all ailments and prolong human life. Therefore alchemy was often practiced by magicians, sorcerers, and people who wanted to make a quick profit (Al-Farabi, 1987: 187-188). Al-Farabi saw all this with his own eyes, heard and lived among them. Therefore, he tried to prove that alchemy is a very important science and a great art.

In the Middle East, al-Farabi was the first to criticize selfish and false alchemists, saying that unfair profit will not lead to good. Abu Nasr Farabi believed that alchemy is necessary for society and can be of significant benefit in revealing the essence of certain chemical processes and compounds, if it is guided by scientific principles and does not pretend to be impossible.

According to a contemporary of Farabi, the famous chemist Jabir ibn Hayyan, "The job of a physicist and a chemist is to conduct experiments. One can only get knowledge through experimentation" (Frolova, 1983, p. 98). Abu Nasr Al-Farabi in his treatise fully agrees with the opinion of his contemporary and recommends, before engaging in the craft of alchemy, to study this science and look at the results of his knowledge through various experiments.

Abu Nasr Al-Farabi divides alchemists into two groups. Representatives of the first group reject and falsify this art, while representatives of the second group approve of the art of alchemy, but abuse is potential. Both groups are wrong in their views, and alchemists have tried to complicate the science of alchemy by describing it in a way that only they can understand, adding different verses to keep it secret. That is why the science of alchemy for a long time known only to a certain group of people and was a secret science incomprehensible to ordinary people. However, according to Al-Farabi, if we look closely at the written data on the art of alchemy and descriptions of alchemists, there are no analogs of gold and silver. There are common gold and silver that we all know about, no more gold and silver exists. If we find any other gold, it will not look like the gold we see. We need some simple logic here. The ignorant person believes that gold and silver can make from ordinary stone. However, an educated person would never believe such a lie. According to Farabi, to better understand the craft of alchemy, it is necessary to study it completely, and first of all better start from studying mineralogy. Before studying mineralogy, you need to study Philosophy. A comprehensive study of all aspects of philosophy reveals the true nature of things and leads to absolute wisdom. He believes that only a philosopher can achieve absolute wisdom (AlFarabi, 1987: 188-190).

Abu Nasr al-Farabi, having studied the treatises of Aristotle and other scientists, identified two different aspects of alchemy. First, according to the scientist gold, silver, and other precious metals do not burn, but melt. The difference between metals is not in their form but in their significant and incidental accidents. The second aspect is that the difference between two different substances of 
the same type is only accidental, therefore any two different things of the same kind differ in accidents and any of them can urn into another. If the incident is significant, then the conversion is difficult, and if not significant, then the conversion is easy. Therefore many people have been mistaken and deluded in their proofs about this art and exceeded its capabilities. Al-Farabi concluded that the views of both groups on alchemy are wrong (Al-Farabi, 1987: 191). Al-Farabi considers chemistry as an art is in direct contact with nature, and calls it one type of art that is mastered through many experiments.

We will focus on the treatises "On the organs of the human body", which are directly related to medicine. First, Farabi, like his teacher, Aristotle, called medicine one type of experimental art. More precisely, medical science, like alchemy based on experience. And its object is the human body and its organs. The art of medicine can master in practice. To conduct an experiment, the doctor needs the body and organs of the animal. Aristotle attributed man to "animals". In addition, when treating the human body, it is very important to treat the "Man" himself. He noted that you can study a person by studying his nutrition. He divided human food into three types. These are animals, plants, and minerals. Since humans use animal flesh, the physician needs to be familiar with animal diseases. Otherwise, he cannot cure completely and properly. All people use minerals and plants in their food. The same requirements apply to plants and minerals. In addition, the physician must know the entire human body. The diseases can identify by knowing the structure and characteristics of each organism. As you can see, the doctor needs to study animals, plants, and minerals to heal a person. The doctor's weapon is proper nutrition, medicine, and scalpel, etc (Al-Farabi, 1987: 143). In fact, modern medicine explains that proper nutrition is the key to good health. And in the Middle Ages and now it means that when using meat dishes, you need to cook them correctly and use them with extreme caution. Having got acquainted with the treatise of Al-Farabi, we convinced that the instructions of doctors not to eat the meat of sick animals and properly store meat products were relevant not only today but also in the time of Al-Farabi. As you can see, mastering the art of medicine requires deep and comprehensive experience, and for a successful experiment, the doctor concluded that it is much easier and more successful if he knows the philosophy of human nature.

\section{Conclusion}

Summing up the results, we once again made sure that Al-Farabi wrote a book on all fields of science. Abu Nasr Al-Farabi was primarily a philosopher and emphasized the need for knowledge of philosophy in the study of each area. Therefore, no matter how much he paid attention to philosophy, he did not bypass the disciplines of medicine, chemistry, anatomy, and biology. He recommended mastering these branches and considered them to be practical branches of science. Al-Farabi repeated each time that a researcher needs to know the philosophy of each branch to understand the nature of the specialty. Second, it is a duty and a great honor for each of us to know how many treatises written by an encyclopedic scientist from the Kazakh steppes. This means a philologist, philosopher, historian, lawyer, doctor and musician, specialists in chemistry, biology, physics and mathematics, and other specialists can, without going too far, glean important information from the treatises of $\mathrm{Abu}$ Nasr Al-Farabi. So far, European scientists have received the most necessary information from the scientists of the East, including from Al-Farabi. We, the countries of the East, are not even familiar with the complete list of the works of this remarkable scientist. Therefore, this year, within the framework of the $1150^{\text {th }}$ anniversary of the scientist, there is a great opportunity to correct these shortcomings. We, also propose to include information from a small treatise by Al-Farabi "On the necessity of the art of alchemy" in the preface to textbooks for students who are just starting to study chemistry (grade 7). If every student in the country studies chemistry with Abu Nasr Al-Farabi's words about chemistry, their interest and enthusiasm for the subject will increase. In addition, when studying such disciplines as literature, history, poetics, music, mathematics, physics, social sciences, law, etc., it is important to start with the works of Abu Nasr Al-Farabi.

Abu Nasr Al-Farabi lived in the Middle Ages, but he is even now a modern scientist. He has a topic for a conversation with every specialist. He has something to say to every reader if only he knew how to listen ..... 


\section{References}

Al-Farabi,M. (1972). Mathematical treatises / Abu Nasr al-Farabi; Academy of Sciences KazSSR, Institute of Philosophy and Law. Alma-Ata: Nauka.; Al-Farabi,M. (1972) Logical treatises. Alma-Ata: Nauka.; Al-Farabi,M. (1972) Comments on "Almagest" Ptolemy. A-Ata: Nauka.; Al-Farabi,M. (1973) Philosophical treatises, Almaty: Nauka.; Al-Farabi,M. (1974) Treatises on music and poetry. Almaty: Nauka.; Al-Farabi,M. (1975). Socio-ethical treatises. Almaty: Nauka.; Al-Farabi,M. (1975). Philosophical treatises / Abu Nasr al-Farabi; Academy of Sciences KazSSR, Institute of Philosophy and Law. Alma-Ata: Nauka.

Al-Farabi (1987). Natural science treatises. Translation from Arabic language / Abu Nasr al-Farabi; Academy of Sciences of the Kazakh SSR, Institute of Philosophy and Law. - Alma-Ata: Publishing house of the Academy of Sciences of the Kazakh SSR. - 495 p.

Corben, H. (1373/1994) History of Islamic Philosophy. Tehran: Kavir, P. 224.

Halabi, A.A. (2002) The history of Iranian philosophy. Tehran: Zuvvar, P.146.

Khairullaev, M.M. (1973) Farabi - the greatest thinker of the Middle Ages (to the $1100^{\text {th }}$ anniversary of the birth of Abu Nasr Farabi). Tashkent: Fan, P. 14

Sadri, M. (1374) The biography of famous people of Iran. Tehran: Abnus, P. 32.

Bayt al-Hikma: https://www.britannica.com/place/Bayt-al-Hikmah

Al-Farabi, M.(1987) Natural science treatises. Translation from Arabic langauge / Abu Nasr al-Farabi; Academy of Sciences of the Kazakh SSR, Institute of Philosophy and Law. - Alma-Ata: Publishing house of the Academy of Sciences of the Kazakh SSR, P. 9.

Pichkhelauri, G.Z. (1971) Medical-scintefic knowledge of Al-Afarabi / Soviet Healthcare, №8. pp. 75-77.

Balmukhanov, S.B. (1975) Al-Farabi and development of medicine in the East / Al-Farabi and development of science and culture in the East: abs.report. Alma-Ata, pp. 64-67.

Chokin, A.R. (1976) Al-Farabi and his significance in the field of natural science and medicine / The materials of $45^{\text {th }}$ science conference. Alma-Ata, - Issue 1. pp. 3-5.

Kaziberdyev, A.A. (1978) Little known medical-philosophical treatise of Al-Farabi / Philosophical Issue. - №10. pp 134-136.

El-Fakkaki, B. (2012) Cosmic Justice in Al-Farabi's Virtuous city / Thesis submitted for the degree of Doctor of Philosophy at King's college University London. pp. 62, 89, 94, 98, 117-118.

Frolova, E.A. (1983) The problem of faith and knowledge in Arab philosophy. Moscow: Nauka. P. 98. 